\title{
ПОРОВНУЮЦИ ИДИОМИ З ДЇєСЛОВАМИ У РУСКИМ ЯЗИКУ И ЇХ СЕРБСКИ ЕКВИВАЛЕНТИ*
}

У роботи ше анализую поровнуюци идиоми хторим поровнуюца часц дїєслово. Виглєдованє облапело 232 поровнуюци идиоми руского язика хторим дїєслово перша часц, односно компарандум. Попри анализи состава руских идиомох, у роботи обезпечени и їх сербски еквиваленти. Автор сербски еквиваленти класификовал на цалком еквивалентни идиоми, часточно еквивалентни идиоми и описни еквиваленти. Робота обезпечує и одредзени статистични податки о руских идиомох и перши информациї у русинистики о заступеносци дзепоєдних сегментох структури

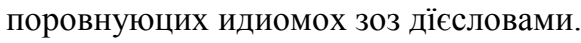

Ключни слова: руски язик, сербски язик, идиоми, поровнуюци идиоми зоз дїєсловами, прекладни еквиваленти.

\section{УВОД}

Єден 3 найчежших сегментох при ученю єдного язика то його фразеология. Тото виглєдованє ма за циль помогнуц бешеднїком руского язика систематизовац руску фразеологию и оможлївиц им же би лєгчейше звладали сербски еквиваленти. Цалком ясне же ше нє можеме у подполносци виражовац або розумиц других кед зме нє упознати зоз найчастейшима фразеологизмами датого язика. Вираз фразеологизм у рускей лингвистики хасновал Юлиян Рамач (Ramač, 2002: 456). У сербскей лингвистики, паралелно $30 з$ термином фразеологийна єдинка, вираз фразеологизм хасновала и Драгана Мршевич-Радович (Mršević-Radović, 1987: 11). Авторка наводзи же у хаснованю и шлїдуюци термини: идиом, идиоматска фраза, устаємнєна

\footnotetext{
*fejsam@gmail.com

** Робота настала як продукт проєктох 187002 (Язики и култури у часу и простору) и 187017 (Дискурси меншинских язикох, литературох и културох у юговосточней $и$ стреднєй Европи), хтори финансує Министерство просвити, науки и технологийного розвою Републики Сербиї.
} 
фраза, фразеологийни обрат (вираз, конструкция), устаємнєни обрат (конструкиия), фразем (ibid.). Як синоним тим термином ми у тей роботи будземе хасновац термин идиом (спрам: Varga-Groszler, 2008; IvanovskaGroszler, 2011). Идиом представя порядок словох (термини, вирази або виреченя) хтори стабилни у своєй структури и значеню. Значенє идиома нє препознатлїве гоч познати поєдинєчни значеня конститутивних словох та го прето нєобходне спатрац як цалосц. Идиомске значенє створене з общим хаснованьом у периодзе од велїх деценийох або викох и характеризує го конвенционализованосц.

Цо ше дотика поровнуюцих идиомох, хтори тема тей роботи, вони представяю формални вязи найменєй двох словох. За розлику од идиомох у хторих пришло до подполней десемантизациї лексемох (кед нове значенє нєпрепознатлїве бешеднїкови) значенє поровнуюцих идиомох углавним мож заключиц на основи значеньох состойних часцох (напр. виси як витор, сцекач як заяи). У основней структури поровнуюцого идиома ясно ше видзелюю три часци:

1. часц А (лїви бок), часц хтора ше поровнує;

2. часц Б, поровнуюца частка (Kovačević, 2012) або поровнуюци злучнїк як (Fink-Arsovski, 2002), цо тримаме за одвитуюцши термин бо упут ює на функцию дотичного слова у поровнуюцих идиомох;

3. часц В (прави бок), часц зоз хтору ше перша часц поровнує.

И у славистичней и у англистичней литератури поровнуюци идиоми ше дзеля у зависносци од файти словох хтори ше зявюю на лївим боку структури. Так напр. Дженифер Сеидл и Вилиєм Мекморди у английским язику розликую: 1. поровнуюци идиоми зоз прикметнїками (as merry as a cricket); 2. поровнуюци идиоми зоз дїєсловами (to drink like a fish); 3. розлични поровнуюци идиоми (to be like a red rag to a bull, as quick as a dog can lick a dish) (Seidl-McMordie, 1987: 223). Поровнуюци идиоми у английским препознатлїви по like и as soon as, у сербским по као и попуm, а у руским виключно по як. Йосип Матешич предклада розробеншу класификацию за горватски язик, хтору прилапює и Мария Омазич (Omazić, 2002: 106), а хтору и ми хаснуєме у тей роботи та по файти словох у позициї компарандума (часци А) руски поровнуюци идиоми групуєме на:

1. поровнуюци идиоми зоз прикметнїками (напр. красна як бабка);

2. поровнуюци идиоми $з о з$ дїєсловами (напр. роснуц як з води); 
3. поровнуюци идиоми 303 меновнїками/меновнїцким виразом (напр. гарсции як лопати);

4. поровнуюци идиоми 303 присловнїками/присловнїцким виразом (напр. жимно як у лядовні);

5. такв. нулти тип, кед компарандум випущени; то ше одноши и на идиоми у хторих випущени форми дїєслова буи (напр. як оси).

Зоз поровнуюцима идиомами ше жада єдно поняце оквалификовац, зробиц познатшим 303 приводзеньом до вязи по даякей прикмети 303 познатшим поняцом, при хторому тота прикмета виражена у вельким ступню и общепозната. Зоз поровнованьом ше змоцнює значенє (прикмета) поняца, одкриваю ше подобносци, алє и розлики хтори существую медзи поровнуюцима поняцами (Mršević-Radović, 1987: 42)

Виглєдовацки корпус формовани на основи капиталного лексикографийного дїла Руско-сербски словнїк (Ramač-Timko-Djitko-Medješi, $\&$ Fejsa, 2010), хтори обезпечує и сербски еквиваленти. При запровадзованю еквивалентности ми на становиску Вернера Колера хтори трима же еквивалентносц подрозумює еквивалентни поняца у специфичних ЖТ - ЦТ (жридлови текст - цильни текст) парох и контекстох и же мож розликовац “пейц розлични файти еквиваленциї: (а) денотативну еквиваленцию хтора уключує звонкалингвистични контекст єдного текста, (б) конотативну еквивалентност хтора ше односи на лексични вибор, (в) текстуално нормативну еквиваленцию хтора ше одноши на типи текстох, (г) прагматичну еквиваленцию хтора уключує примателя тексту або порученя, и (г) формалну еквивалентносц хтора ше одноши на форму и естетику текста" (Koller, 1979: 186-191, спрам Panou, 2013: 4; Baker-Saldahna, 2011: 96-97).

\section{ПОРОВНУЮЦИ ИДИОМИ 3 ДЇЄСЛОВАМИ И ЇХ СЕРБСКИ ЕКВИВАЛЕНТИ}

У тим поглавю представиме руски поровнуюци идиоми з дїєсловами и їх сербски еквиваленти. Кед слово о сербских еквивалентох ми розликовали три файти, хтори зме и окреме означели: 1. цалком еквивалентни идиоми (хтори у списку подцагнути), а хторим идентични шицки три часци; 2. часточно еквивалентни идиоми (хтори у списку визначени з курзивом), а хторим идентична часц Б и углавним часц А; 3. еквиваленти хтори нє представяю сербски идиом, алє толкованє значеня руского идиома (вони у списку нє визначени окреме). 
Сумираюци терминологию у восточнославянскей традициї, Светлана Голяк визначує же ше часц А наволує и базна часи поровнованя, тема и лїва часи, а часц Б еталон, рема и права часи. Така структура подрозумює же ше у устаємнєних поровнованьох одвиваю семантични процеси окремней природи засновани на зблїжованю референта и еталона, алє нє и на їх виєдначованю як цо то случай при метафорох (поровнац Вон матарец и Вон глупи як матареи) (Goljak, 2009: 211).

У Руско-сербским словнїку, чия сербска часц базована на шейсцтомним словнїку Матици сербскей, находзиме шлїдуюци идиоми:

1. жиц як у раю : живети као мали бог (као бубрег у лоју);

2. шпива (крашнє) як ангел (ангелчок) : пева анђеоским гласом, пева лепо као славуј;

3. шмати на нїм стоя як анц : одело на њему стоји као саливено;

4. нагнївал ше як бабин пес : навукао му се облак на чело;

5. шедзиц (ляпнуц, лєжиц) як (тота) здохлїна (губаба, балєга) : ни мрднути;

6. ма розум як у крави : он има кокошију памет;

7. набрац (натрепац) на себе як на роги : натрпати себи на главу;

8. бежац як бдзина : жива жеравица;

9. шмердзиц як бдзина : смрдети као твор;

10. буц вецей бити як сити : добијао је грдних батина;

11. жиц як кед би поєдли герлїче гнїздо (герлїчата) : живе као голубови, једна душа једно тело;

12. роби (цага) як бияла : ради као коњ;

13. єст дачого як блата : има чега као хладне воде;

14. збиц дакого як блато : убити бога у њему;

15. жиц себе як мали бог (як у кральовским дворе, як у вельким сакайтове) : живети као мали бог, живети бог богова, живети као бубрег у лоју;

16. одруциц дакого/дацо як стару бочкору : баџити кога/ито као стару канту;

17. познац дакого/дацо як стари бочкори : познавати кога/што као свој иел;

18. заспац як на бригу : заспати као за инат;

19. спац як бундаш : спавати као топ;

20. войсц як витор (буря) : улетети (банути) као вихор (бура);

21. пада шнїг як вайца (тащата) : падају врапчије главе; 
22. ма брух як ванджух : има трбушину, има стомачину као гајде;

23. бегац (ходзиц) як з веслом : трчати као мува без главе;

24. весц ше як пред нєдобрим : то слути зло

25. ходзиц як по винглю (як з винглю) : ићи (ходати) као мува без главе;

26. прибрал (вирихтал) ше як до винчаню : накинђурио се као нова (сеоска) млада;

27. ходзи як вирколап : хода као да је мало онако;

28. знац як Вирую : знати као Оченаш, знати у прсте;

29. вистац як поштарски конь (як югаски пес) : уморан као пас, мртав уморан;

30. бешедовац як до витру : брбљати у ветар;

31. висц як витор : излетети као ветар (вихор);

32. войсц (улєциц) як витор : банути као ветар, улетети као бомба;

33. роснуц як з води : расти као из воде (као врба из воде);

34. дац дакому як волом (як волови) : дати коме као за војску;

35. єсц як вол : јести као мећава;

36. прейсц як вол : проћи као поред турског гробља;

37. врациц дакому як себе пожичел : вратити коме мило за драго (шило за огњило);

38. бегац як врецено : врти се као чигра, јури као мува без главе;

39. буц цихо як вша/уша у храсти : ћутати као риба (као оловом заливен);

40. верциц ше як вша/уша у храсти : непрекидно се врпољити;

41. приповедац (плєсц) як галабурда : причати тандара-мандара;

42. бежац як гаче опрез друка : истрчавати као ждребе пред руду;

43. идзе до ньго як до герчковей дзири : има велики стомак;

44. скочиц (руциц ше) як герчок : скочити као опарен;

45. робиц (исц) як без глави : радити (ићи) као (мува) без главе;

46. догвариц ше як глухи и нєми : никако се нису договорили;

47. шедзиц як глухи : ћутати као заливен (пањ, риба);

48. сплєтац як у горучки (як на глушку) : булазнити;

49. скруциц як за гнойом (як за брадлом) : лупити, бубнути;

50. прейсц як голи у покриви : провести се као бос по трњу;

51. скакац (бегац, нарабяц) як гопштур : скакати (трчати, изводити) као будалица;

52. бешедовац як зоз гордова : говорити као из бурета (бачве);

53. замарзнул як грублє (як цомпля) : прозебао је до костију; 
54. поробиц як гевтот цо гачи скрал : урадити као да има две леве;

55. (на)биц дакого як говеду : (ис)тући кога као вола у купусу;

56. давац як з меха (як нє зоз свойого) : давати и шаком и капом;

57. спораїц (ушориц) дакого як Демко писи нину рапаву : средити некога ко Панта питу;

58. дзбац за дачим як пес за пияту ногу : марити као пас за пету ногу (као за лањски снег);

59. ходзиц як шалєни 3 дзверми : мотати се као шијак;

60. швечи му як псу дзвончок : пристаје му као магариу седло;

61. плакац як диждж : плакати као киша;

62. биц ше до шицкого як донгов : ићи гегаво;

63. стац як древена Мария : стајати као кип (као дрвени светаи);

64. спац як древо (як зарезани) : спавати као клада (као заклан);

65. пиц як дуга : пити као дуга (као смук);

66. дудрец як Банячко : непрекидно гунђати;

67. дуц ше як пуляк : јако се дурити;

68. дал Бог душу як до пняка : дрвендека;

69. бежац як без души : трчати као без душе;

70. сцекац (бац ше) як дябол од крижа : бежати (бојати се) као ђаво од крста;

71. єднац ше як Бульчик з новтарушом : не могу да се договоре;

72. клїпкац як жаба у мутлянки (у студзенїни, у кислим млєку) : гледа као телац;

73. уперац ше як жаба у праху : тера своје;

74. женїц як Янка у Коцуре : правити рачун без крчмара;

75. чекац як жертва : чекај коњу док трава нарасте;

76. розвязац ше як жидовски мех : развезао је језик;

77. жиц як у раю (як у кральовским дворе) : живети као у рају, живети као бубрег у лоју;

78. чувац як жренко ока (у оку) : чувати (пазити) као зеницу ока свога;

79. забиц дакого як пса : убити кога као пса;

80. забуц як умарти : потпуно заборавити;

81. сипе диждж як задармо : лије киша непрестано;

82. звлєкол ше як зайда : вуче се као пребијена мачка;

83. шедзиц як закутна баба : седети у запећку;

84. буц як залєтнїк : бити пети точак у колима; 
85. вшадзи ше винайсц як варешка у запражки : бити у свакој чорби мирођија, бити сваком лонцу поклопац;

86. заспац як зарезани (як мертви) : заспати као заклан (као мртав);

87. спац як заяц : спавати као зец;

88. сцекац як заяц : бежати као без главе;

89. згуркнуц ше на дакого як врани : дигли су на њега галаму;

90. глєдац як иглу : тражити као иглу у сену;

91. лєє як з кабла (з цивох) : лије као из кабла;

92. познац дакого як стари календар : познавати кога као свој цुеn;

93. дознац од нього чежко як $з$ каменя : тешко је од њега сазнати;

94. лашиц ше (патриц, пажериц ше) як кандур на колбаси : иде му вода на уста, расту му зазубице;

95. чекац як каня дижджу : чекати као озебао сунце;

96. кричац (вадзиц ше) як у карчми : понашати се као у крчми;

97. бежац як каче (качата) за ягоду : трчати као без главе;

98. чвиркац як квока : блебетати;

99. шедзиц як квока на вайцох : седети као квочка на јајима;

100. клїпкац як жаба у мутлянки : гледати (буљити, зијати) као теле у шарена (нова) врата;

101.бешедовац (гуториц) як кед би з кнїжки читал : говорити као из књиге (као да чита);

102. кобдзи на пипки як з комина : дими као из очака;

103. коборлує як тота швиня у оборе : прави лом као свиња у обору;

104. треба му як псу пията нога : то му уопште не треба;

105. вирос як за комином : порастао је као да су га ђаволи за уши вукли;

106. кури як комин : пуши као оџак;

107. корци го як Словака жемлїк : веома га копка;

108. вецей вредзи як кошта : има вредност али нема цену;

109. идзе му робота як малому дзецку кошулька до задку : иде му посао као чарапин почетак;

110. кричиц (йойчиц, дрец ше) як кед би з нього скору дарли : дере се до седмог зноја;

111. подруциц дакому дацо як куковка вайцо : подметнути коме што као кукавица јаје;

112. бежац (лєциц) як куля : јурити као метак;

113. крачац як куля : ићи стабилним кораком; 
114. круци ше як кура з вайцом : хода овамо-онамо не знајући шта да почне радити;

115. розумиц ше як кура до пива : разумети се у што као магарац у кантар;

116. замервиц ше як курче до клоча : заплести се као пиле у кучине;

117. латац ше як шлєпи на очи : грабити се постићи нешто;

118. стої як магарец медзи овцами : стоји скрштених руку;

119. тарговиц з Руснаком як з дробним маком : са Русином не вреди трговати јер он само ситну робу продаје и купује;

120. почервенїц як маков квет : поцрвенети до ушију;

121.цадзи ше (розцагує ше) як малєй (олєй, цмар) : вуче се као ладовина;

122. пада як мана з нєба : пада као мана с неба;

123. идзе як подмацене (як по машлє) : иде као подмазано;

124. єсц як маче : јести као врабаи;

125. бавиц ше 3 даким як мачка 3 мишом (мишу) : играти се с неким као мачка с мишем;

126. жиц (складац ше) як пес и мачка : живе (слажу се) као пас и мачка;

127. лїпню ше на ньго / ню як мухи на мед : иду као пчеле на мед;

128. махац з даким як зоз стару метлу : окретати кога око малог прста;

129. присц як на метли : улетети као бомба;

130. давац (дзелїц) як $з$ меха (як з нє свойого) : давати шаком и капом;

131. розвязал ше як жидовски мех, сипе ше 3 нього як 3 торби : развезао је језик;

132. спаднуц як мех : пасти као пун џак (као клада);

133. фучац як мех : јако дахтати;

134. чежко наполнїц як дзирави (подарти) мех : бачва (буре) без дна;

135. пошло як з мидлом : отишло је као по лоју;

136. нє видно це як билого миша (билу мишу) : не даш се видети;

137. змокнуц як миша (миш) : покиснути као миш;

138. цихо є як у мишей дзири : ћути као риба (као заливен);

139. шедзиц як млода : седи као принцеза;

140. влапиц ше до дачого як моль до кожуха : прионути на посао;

141. круци ше (бега, ходзи) як мотога : трчи (хода) по целом селу не мирујући; 
142. мучиц дакого як Жидзи Христа : распињати (приковати) кога на крст;

143. робиц як мушка : радити као црв;

144. навалєл як буяк на червене : навалио као сивоња;

145. набиц дакого як неплеху : издеветати кога;

146. ведзе ше му як пред нєдобрим : то слути на зло;

147. любиц дакого як коза нож (а фаркаш капусту) : волети кога као очи хрена;

148. ходзиц як тота нора, войсц як нудза : ходати као мува без главе;

149. обрац дакого як куру до гарчка : узети коме све до голе коже;

150. буц таки як одрутка : бити пети точак у колима;

151. шедзи як на ожогу : седи као на иглама;

152. мерковац як на два очи : чувати као око у глави;

153. опиц ше як швиня : опити се као свиња (као ћускија);

154. остац як на оцилки : остати без ичега;

155. пошло му як на оцилку : испало му је наопачке;

156. знац дацо як Оченаш : знати нешто као Оченаш (као својих десет прстију);

157. исц (ходзиц) як тота пава : гордо (поносно) ходати;

158. жиц себе як пес на паздзерчу : живети као пас на ланиу;

159. идзе му робота як малому дзецку до пелюшки : иде му посао као чарапин почетак;

160. дзбац як пес за пияту ногу : марити као пас за пету ногу (као за лањски снег);

161. набиц дакого як пса : истући као вола у купусу;

162. пойсц як пес з косцу : отићи као покисао пас;

163. треба ци то як псу пията нога : то ти уопште не траба;

164. циганї як пес : лаже као псето;

165. швечиц як псови дзвончок : пристајати као пилету сисе (као крави седло);

166. уми(ва)ц руки як Пилат од Христа : (о)прати руке као Пилат;

167. плациц як не 303 свойого (як з люцкого); плаћати као народна банка;

168. мац пенєжи як плєви : имати пара као криа, лежати на парама;

169. мац пенєжи як Жид плєви : бити као црквени миш;

170. познац дакого/дацо як святи Боже : познавати кога/што у душу;

171. войсц як курче до помийох : наивно упасти у невољу;

172. одруциц дакого як помиток : бацити кога у старо гвожђе; 
173. вирос як поскона : порастао је висок као гора;

174. бегац як з посолєну : бити прави вртиреп;

175. приповедац як кед мокре гори : млатити празну сламу;

176. пришкапело ше му як шлєпей кури зарно : посрећило му се као ћоравој кокоши да нађе зрно;

177. спущиц нос як пуляк : обесити (спустити) нос;

178. розсипал ше як пушков барут : раздрешио је бисаге;

179. збляднуц як ренда : пребледети као крпа (као зид);

180. зарепиц ше (прилїпиц ше) як репик : прилепити се као чичак (као крпељ, као таксена марка);

181. маю тельо дзеци як на речици дзирки : имају буљук деце;

182. вичухал ше як риняве праше : као дете био је нерадан а касније је постао вредан;

183. роби як брамушка з хвостом (як мертви з очми) : посао му иде као чарапин почетак;

184. дац ше до роботи яж Жид Мишков кулаш : радити као коњ;

185. бега як розвора : само трчи, никако не мирује;

186. розвязал ше як жидовски мех (як з торби) : развезао је језик;

187. облєкол ше як рондьош : обукао се као одрпанащ;

188. достал (пришло) як з рукава витрешене : добио је као на тањиру, пало му је као зрела крушка;

189. познац дакого як святи Боже : у душу познавати некога;

190. бешедовац як нє при себе : бунцати;

191.буц як нє при себе : бити ван себе;

192. надзера ше (дре ше) як кед би з нього скору дарли (як кед би го дарли) : дере се као да га жива деру (као да га кољу);

193. лєжац як сноп (як древо) : лежати као клада;

194. шедзи як спасибагов : седи као пањ;

195. буц як живе стрибло : бити као живо сребро (жива);

196. треше ше як студзенїна : дрхти као шиба на води (као прут);

197. цага ше (влєче ше) як кравске счисциско (як швиньски черева, як

бураги) : вуче се као пребијена мачка (као ладовина);

198. пада шнїг як тащата : падају врапчије главе;

199. поотверали уста як тащата : деца су широм поотварала уста;

200. тримац дакого як квеце у погаре : држати кога као мало воде на длану;

201. присц як туз на єденац : доћи као кец на десетку; 
202. шедзи як туз : седи важан, охол;

203. буц цихо як уша у храсти : ћутати као заливен;

204. вшадзи ше винайдзе як уша : свуд се утрпа где га не треба;

205. могол би лєциц як фицерий : кост и кожа;

206. ходзи як францияш : има икс-ноге;

207. ходзиц за даким як хвост (хвосцик) : пратити некога као сенка;

208. робиц (трапиц ше) як хринов хробак : ради полако тежак посао;

209. рихтац ше як худобни (цар) до войни : дуго се спремати за одлазак;

210. цадзи ше як малєй (цмар) : вуче се као ладовина (као пуж, као рак);

211. патриц як целє на нову капуру : гледати као теле у шарена врата;

212. цеши ше як Бораї у мачецу : поноси се нечим неважним;

213. вищирел очи як цибулї : исколачио је очи;

214. кричи (звискує) як тот чикош : виче (дере се) из свег гласа;

215. роби як шаркань : ради као ирнац;;

216. влєче ше (цага ше) як шарканьов хвост (як тота швеценїна): вуче се као пребијена мачка;

217. мерац як злато : мерити као у апотеци;

218. є як шашка : једе као мећава;

219. исц як шашка : ићи као на чудо;

220. нє буц як други швет : не бити као сав свет;

221. пойсц видзиц як швет стої : отићи упознати свет;

222. вшадзи ше винайдзе як швиня у бундавох : где год дође, направи штете;

223. стац просто як швичка : стајати усправно као свећа;

224. знац плївац як шекера до сподку : пливати као секира;

225. роснуц як шефа : расти као коров;

226. буц слаби (худи) як шитар : бити сенка од човека;

227. бежи як шлєпе : трчи као без главе;

228. пошол як богатому по шмерц : као да смо га по смрт послали;

229. облєчени є як шнурка : јако лепо је обучен;

230. ма язик як у крави хвост : има језик као крава;

231. то ище як так : то је још Боже помози. 


\section{АНАЛИЗА ВИГЛЄДОВАЦКОГО КОРПУСА}

У виглєдованим жридлу, у Руско-сербским словнїку, находза ше 232 руски идиоми у хторих поровнуюца часц (лїва часц, часц А) дїєслово. 3 оглядом на то же дзепоєдни идиоми маю и два еквиваленти у сербским язику наш виглєдовацки корпус уключує 281 сербски еквивавалент. Цалком еквивалентни идиоми (хтори у списку подцагнути), а хторим идентични и часц А и часц Б и часц В, єст 53. Часточно еквивалентни идиоми (хтори у списку визначени з курзивом), а хторим идентична часц Б, єст 109; 87-мерим 3 нїх идентична и часц А. Еквиваленти хтори нє представяю сербски идиом, алє свойофайтове толкованє значеня руского идиома, єст 119. Процентуално виражене цалком еквивалентни идиоми єст 19\%, часточно еквивалентни идиоми $39 \%$, а описни еквиваленти $42 \%$.

Найчастейши дїєслова у поровнуюцих идиомох хторим компарандум дїєслово то дїєслова хтори описую чловеков стан (насампредз дїєслово буи) и способ чловекового рушаня (насампредз дїєслова иси и ходзиц).

Дієслово буи у рижних формох зазначене 13 раз (у идиомох под числом 10, 13, 39, 84, 138, 150, 192, 196, 204, 221, 227, 230, 232). Остатнї идиом характеристични по тим же форма дїєслова буи у трецей особи презента $(\epsilon)$ випущена бо субєкт виповедзени. Кед то маме у виду мож повесц же ше и при поровнуюцих идиомох хторим компарандум меновнїк або заменовніїк стретаме зоз випущенима формами дїєслова буи (напр. Hou [є] видна як дзень).

Дїєслово иси зазначене 7 раз $(43,45,109,123,157,159,220)$ а його префиксовани форми пойси 5 раз $(135,155,162,222,229)$, войси 3 раз $(20,32$, 172), приси 3 раз $(129,189,202)$, а виси и прейси по раз $(31,36)$. Дїслово ходзии зазначене 9 раз $(23,25,27,59,141,148,157,207,208)$. Обачуєме и други дїєслова рушаня: бежаи / бегаи (8, 23, 38, 42, 51, 69, 97, 112, 141, 175, 186, 228), сцекаи $(70,88)$, скочии / скакаи (44, 51), лєции (112), крачаи (113); дзепоєдни похасновани пейоративно: звлєчиц ше / влєчии ше (82, 198, 217), винайси ше $(85,205,223)$, круции ше $(114,141)$, цадзич ше $(121,211)$, цагаи ше (198, 217), вериии ше (40), скруции (49), бии ше (62), згуркнуи ше (89), коборловаи (103), розцаговаи ше (121), махаи (128), навалій (144).

Медзи фреквентнима дїєсловами и робии / поробии (12, 45, 54, 143, 184, 209, 216), шедзии $(5,47,83,99,139,151,203)$ м маи $(6,22,169,170,182$, 206), жии $(1,11,15,77,126,158)$, спаи / заспаи $(18,19,64,86,87)$, даи / даваи (34, 56, 68, 130, 185), бич / набии / збии $(14,55,145,161)$, знач / дознаи $(28,93$, 


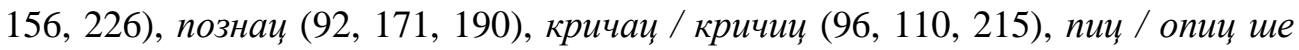
$(65,153)$ и др.

Часц В поровнуюцого идиома зоз дїєсловами часто уключує назви животиньох пес $(4,29,58,60,79,104,126,158,160,161,162,163,164,165)$, кура $(114,115,149,177)$, швиня (103, 153, 198, 223), миш / миша $(125,136$, 137, 138), вша / уша (39, 40, 204, 205), крава (6, 198, 231), вол (34, 35, 36), таще (21, 199, 200), жаба (72, 73, 100), мачка (125, 126), маче $(124,213)$, квока (98, 99), курче (116, 172), герчок (43, 44), шашка (219, 220), шаркань (216, 217), донгов (62), пуляк (67), трамушка / брамушка (184), бияла (12), буяк (144), кандур (94), каня (95), куковка (111), герлӥчка (11), матарец (118), овца (118), конь (29), заяц (87), врана (89), гаче (42), каче (97), цуелє (212), говедо (55), моль (140), мушка (143), коза (147), фаркаш (147), пава (157), пуляк (178), праше (182), кулаш (184), хробак (209), иитар (227), вирколап (27). У сербских еквивалентох заступени шлїдуюци назви животиньох: nac / ncemo $(29,58,79,126,158,160,162,164)$, мачка $(82,125,126,198,217)$, мува $(23,25$, 38, 45, 148), кокошка / квочка $(6,99,177)$, миш $(125,137,170)$, кою $(12,75$, 185), врабаи $(21,124,199)$, теле / телаи $(72,100,212)$, риба (39, 47, 138), во (55, 161), магарач $(60,115)$, свиња (103, 153), пиле (116, 165), крава $(165,232)$, сивоња (144), смук (65), зеч (87), кукавица (111), пчела (127), ирв (143), крпељ (181), пуж (211), рак (211), славуј (2), голуб (11), твор (9), ждребе (42). У литератури ше визначує же у случаю приписованя людских прикметох животиньом приходзи до двойнїстей метафоризациї бо ше прикмети хтори ше перше приписую животиньом познєйше хасную у опису чловека (Vidović Bolt, 2007: 417; Bunk-Opašić, 2010: 238).

У значним чишлє идиомох заступени предмети и продукти вязани за обисце, як и часци обисца: мех $(56,76,130,131,132,133,134,187)$, метла (128, 129), куля (112, 113), весло (23), винлля (25), врецено (38), гордов (52), криж (70), зайда (82), варешка (85), игла (90), кабел (91), кнїжка (101), пипка (102), клоче (116), мидло (135), нож (147), гарчок (149), ожог (151), паздзерче (158), помиток (173), ренда (180), барут (179), торба (187), погар (201), швичка (224), шекера (225), сноп (194), речица (182), друк (42), плєва (169, 170), зарно (177); комин (102, 105, 106), дзвери (59), цүива (91), обор (103), гной (49), брадло (49), капура (212); бочкора (16, 17), гачи (54), кошулька (109), кожух (140), пелюшка (159), рукав (189), шнурка (230); студзенїна (72, 197), цџмар (121, 211), кисле млєко (72), запражка (85), колбаса (94), жемлїк (107), олєй (121), мед (127), пиво (115), рондьош (188). Дзепоєдни зоз наведзених лексемох одражую живот у обисцу у прешлосци та идиоми з нїма за млади генерациї представяю архаизми. 
Мале число идиомох уключую желєняву або рошлїни, напр. каnycma (147), циибуля (214), бундава (223), мак (120), покрива (50) и др.

Дзепоєдни поровнуюци идиоми уключую поняца хтори ше дотикаю духовней сфери, углавним християнскей терминологиї: Бог (15, 68, 171, 190), Вируя (28, 156), Жид (142, 170), Христ (142, 167), рай $(1,77)$, ангел / ангелчок (2), древена Мария (63), дябол (70), криж (70), Оченаш (156), Пилат (167).

До поровнуюцих идиомох 303 дїєсловами 303 народох уключени, окрем Жидох (76, 131, 142, 170, 185, 187), Словаци (107) и Руснаци (119).

Генерално патраци, векша векшина поровнуюцих идиомох 3 дїєсловами описую одредзени чловеково прикмети (вонкашнї и нукашнї) и стан у хторим ше чловек находзи. Векшина з нїх похасновани зоз негативнима конотациями.

\section{ЗАКЛЮЧЕНЯ}

На основи Руско-сербского словнїка (Ramaс̌ и др., 2010) у руским язику видзелєни 232 поровнуюци идиоми хторим поровнуюца часц дїєслово.

Найчастейши дїслова у руских поровнуюцих идиомох 303 дїєсловами то буц, иси, ходзиц, бежац, робиц, иедзиц, мац, жиц, спац, биц и дац. Векша векшина поровнуюцих идиомох 3 дїєсловами описую одредзени чловеково прикмети (вонкашнї и нукашнї) и стан у хторим ше чловек находзи.

У часци $3 о з$ хтору ше перша часц поровнує по фреквенциї ше визначую назви животиньох. Зоз животиньох до руских идиомох найчастейше уключени пес, кура, швиня, миш, крава, вша, вол, тащуе и жаба, а до сербских еквивалентох пас, мачка, мува, кокошка, миш, кою, врабац, теле и риба. Идиоми з назвами $30 з$ рошлїнского швета ридши.

Значне число идиомох уключує назви предметох и продуктох вязаних за обисце, алє окрем лексемох мех и комин по фреквенциї ше нє видзелює анї єдна друга.

Менше число поровнуюцих идиомох 3 дїєсловами уключує 11 поняца хтори ше дотикаю духовней сфери, углавним християнскей терминологиї, а медзи нїма найфреквентнєйша лексема Бог.

Од 281 зазначеного сербского еквивалента цалком еквивалентни идиоми єст 19\%, часточно еквивалентни идиоми $39 \%$, а описни еквиваленти $42 \%$.

Вериме же тото поровнуюце виглєдованє оможлїви же би ше у значней мири спатрели подобносци и розлики медзи рускима и сербскима идиомами и 
же будзе хасновите прекладательом 303 руского на сербски и зоз сербского на руски.

\section{Mihajlo Fejsa \\ COMPARATIVE IDIOMS WITH VERBS IN RUTHENIAN AND THEIR SERBIAN EQUIVALENTS}

\section{Summary}

The paper deals with Ruthenian comparative idioms in which the comparandum is a verb. The corpus, based on the Ruthenian-Serbian Dictionary, included 232 comparative idioms with verbs as the first part of the structure. All elements of the structure of comparative idioms with verbs were considered. The most frequent verbs used as the comparandum (e.g. буц, исц, ходзиц, бежиц, робиц, шедзиц, мац, жиц, спац, биц, дац) were indicated, and a conclusion was reached that they mostly express meanings connected to people. Three kinds of Serbian equivalents were also determined: completely equivalent idioms (19\%), partially equivalent idioms (39\%), and translation equivalents (42\%).

Key words: Ruthenian language, Serbian language, idioms, comparative idioms with verbs, translation equivalents

\section{Михајло Фејса \\ ПОРЕДБЕНИ ИДИОМИ СА ГЛАГОЛИМА У РУСИНСКОМ ЈЕЗИКУ И ЊИХОВИ СРПСКИ ЕКВИВАЛЕНТИ}

Сажетак

Рад се бави русинским поредбеним идиомима у којима је компарандум глагол. Корпус, заснован на Русинско-српском речнику, садржи 232 поредбена идиома са глаголима који представљају први део структуре. Аутор посвећује пажњу свим елементима структуре поредбених идиома са глаголима. Он указује на најчешће глаголе који се користе као компарандум (нпр. буц, исц, ходзиц, бежиц, робиц, шедзиц, мац, жиц, спац, биц, дац) и закључује да ти глаголи углавном изражавају значења повезана са људима. Аутор утвђује и три врсте српских еквивалената потпуно еквивалентни идиоми (19\%), делимично еквивалентни идиоми (39\%) и преводни еквиваленти (42\%).

Кључне речи: русински језик, српски језик, идиоми, поредбени идиоми са глаголима, преводни еквиваленти 


\section{LITERATURA}

Baker, M.-Saldahna, G. (eds.) (2011). Routledge Encyclopaedia of Translation Studies. London and New York: Routledge.

Bunk, A.-Opašić, A. (2010). Prilog kontrastivnoj analizi frazema sa zoonimskom sastavnicom u hrvatskome i češkome jeziku. Rasprave Instituta za hrvatski jezik i jezikoslovlje, 36 (2), 237-250.

Fink-Arsovski, Ž. (2002). Poredbena frazeologija: pogled izvana i iznutra. Zagreb: FF press.

Goljak, S. (2009). Ustaljena poređenja u srpskom i beloruskom jeziku sa aspekta idiomatičnosti. U: Naučni sastanak slavista u Vukove dane 38/1. Beograd: Međunarodni slavistički centar na Filološkom fakultetu. 211-220. (Rad štampan ćirilicom.)

Ivanovska, B.-Groszler, A. (2011). Animal Idioms in German and Their Macedonian Equivalents. U: Točanac D.-Gudurić S. (prir.) (2011). Primenjena lingvistika danas - izmedju teorije i prakse. Novi Sad: Društvo za primenjenu lingvistiku Srbije, Filozofski fakultet u Novom Sadu, Filološki fakultet u Beogradu. 27-36.

Omazić, M. (2002). O poredbenom frazemu u hrvatskom i engleskom jeziku. Jezikoslovlje, 3 (1-2), 99-129.

Koller, W. (1979). Einführung in die Übersetzungswissenschaft. Heidelberg: Quelle and Meyer.

Kovačević, B. (2012). Hrvatski frazemi od glave do pete. Zagreb: Institut za hrvatski jezik i jezikoslovlje.

Mršević-Radović, D. (1987). Frazeološke glagolsko-imeničke sintagme u savremenom srpskohrvatskom jeziku. Beograd: Filološki fakultet Beogradskog univerziteta. (Knjiga štampana ćirilicom.)

Panou, D. (2013). Equivalence in Translation Theories: A Critical Evaluation. Theory and Practice in Language Studies, 3 (1), 1-6.

Ramač, Ju. (2002). Gramatika ruskoho jazika. Beograd: Zavod za udžbenike i nastavna sredstva. (Knjiga štampana ćirilicom.)

Ramač, Ju.-Timko-Djitko, O.- Medješi, H. \& Fejsa, M. (2010). Rusko-serbski slovnjik / Rusinsko-srpski rečnik. Novi Sad: Univerzitet u Novim Sadze Filozofski fakultet - Katedra za ruski jazik i literaturu i Zavod za kulturu vojvodjanskih Rusnacoch. (Knjiga štampana ćirilicom.)

Seidl, J.-McMordie, W. (1987). English Idioms and How to Use Them. Oxford: Oxford University Press. 
Varga, A.-Groszler, A. (2008). Animal Idioms and Their Romanian Equivalents. Lucrări ştiinţifice, 40 (3), 369-373.

Vidović Bolt, I. (2007). Metaforika zoonima u hrvatskoj frazeologiji. U: Marjanić S.-Zaradija Kiš A. (ur.) (2007). Kulturnij bestijarij. Zagreb: Institut za etnologiju i folkloristiku. 403-423. 

СЛОВАКИСТИКА 
